\title{
Editorial
}

\section{Constitutional identity and the European Courts}

The Conseil constitutionnel has spoken again. In a decision of 27 July 2006, no. 2006-540 DC, the French constitutional court has further and significantly elaborated on earlier rulings on the status of Community directives in the French legal order. In the summer of 2004, it had ruled, in cases in which it was asked to declare unconstitutional an act of parliament implementing Community directives, that 'the transposing of a Community directive results from a constitutional requirement with which non-compliance is only possible by reason of an express contrary provision of the Constitution' (decisions of, inter alia, 10 June 2004, no. 2004-496 DC and 29 July 2004, no. 2004-498 DC). Very recently, the Conseil d'Etat, France's highest administrative court, took a similar stance in a case in which the constitutionality of a government decree implementing a directive was at stake (Decision of 8 February 2007, Société Arcelor Atlantique et Lorraine et autres).

The constitutional duty to implement directives is based on Article 88-1 of the French Constitution. Not unexpectedly (See Guy Carcasonne, EuConst (2006) p. 301), the Conseil constitutionnel in its ruling of 27 July 2006 now adds that, on the basis of the same Article, the Conseil itself has the duty to verify whether the legislature respects this duty when implementing a directive. In other words, the court will test implementing acts against the directives they intend to implement - it thus clearly accepts the national court's mandate in the European Constitution. In the same decision, however, this European mandate is subjected to a twofold limitation on account of the French Constitution.

The first limitation is the consequence of the strict time limit within which the Conseil constitutionnel is constitutionality required to give its decisions: within a month and, in cases of urgency, within eight days (Article 61 Constitution). According to the French court, this prevents it from asking preliminary questions on the basis of Article 234 EC. Therefore, it will only declare provisions of an implementing act unconstitutional if they are 'manifestly' incompatible with the directive. It added that, if necessary, it is up to the other, non-constitutional, French courts to make a reference to the Court of Justice by way of the preliminary procedure. 
The second limitation to the Conseil constitutionnels European mandate is that the implementation of a directive may not violate a constitutional provision or principle, which is part of France's constitutional identity (la transposition d'une directive ne saurait aller à l'encontre d'une règle ou d'un principe inhérent à l'identité constitutionnelle de la France). Apparently, the notion of an 'express contrary provision of the Constitution' as a limit to the duty to implement directives, which had been subject to divergent interpretations, is exchanged for that of 'France's constitutional identity'. The latter notion, although not necessarily clearer, is certainly more appealing and evocative.

A question left unanswered by the above-mentioned judgments is what should the French courts do in a case in which secondary community law, other than directives, is contested because it allegedly violates France's constitutional identity. In a booklet, one of France's most distinguished constitutional scholars, François Luchaire, the author of innumerable books and articles, has given his answer to this question. ${ }^{1}$ Luchaire (b. 1920), who assisted Charles de Gaulle and Michel Debré in giving birth to the 1958 French Constitution, and who was a member of the Conseil constitutionnel from 1965 until 1974, based his answer on a distinction between the French and the European legal orders which is, according to him, implied in the case-law of the Conseil constitutionnel and the Conseil d'Etat.

According to Luchaire, a French court asked to set aside a national act is acting within the French legal order; hence, the dispute is governed by French (constitutional) law - this is the case of the Conseil constitutionnel being asked to test the constitutionality of a parliamentary act implementing a directive. However, a French court asked to set aside a European regulation is acting within the European legal order, and the dispute is governed by Union law (p. 41/42). In this latter case, only the Court of Justice can dispense French courts from applying a regulation. Does this mean that France's constitutional identity in such a case lies unprotected? Certainly not, for in Luchaire's view, who wrote before the Conseil constitutionnels 2006 ruling, the notion 'express contrary provision of the Constitution' is intimately related to France's national identity, which the Union has the duty to respect according to Article 6(3) EU (The Union shall respect the national identities of its Member States). If community acts other than a directive violate an express contrary provision of the Constitution or, transposed to the wording of the 2006 ruling, France's constitutional identity, the act would have to be submitted to the Court of Justice on account of Article $35 \mathrm{EU}$ or Article 230 (and of course 234) EC (p. 4/45).

If this suggests that the French constitutional identity has to be defended against Community acts by the Conseil constitutionnel in the French legal order and by

\footnotetext{
${ }^{1}$ François Luchaire, Le droit européen. Son application en France (Paris, Economica 2006).
} 
the Court of Justice in the European legal order, there is a formidable obstacle to it: Article $46 \mathrm{EU}$ does not give the Court of Justice competence to rule on Article 6(3) EU - unless of course respect for the constitutional identity is a general principle of Community law. However that may be, Luchaire's interpretation seems to gain a foothold in the case-law of the Court of Justice, as is witnessed by Case88/03, Portuguese Republic v. Commission of the European Communities, Grand Chamber judgment of 6 September 2006. Here the Court proved itself susceptible to the argument that, in defining the framework for the decision whether a (tax) measure of a regional entity is compatible with Article 87(1) EC, reference must be had to the position of the region in the state's constitutional structure. Although it could not help the autonomous region of the Azores in this particular case - the loss of tax revenue it suffered as result of tax reductions for undertakings in the region were compensated by the Portuguese state - the Court ruled that:

58. It is possible that an infra-State body enjoys a legal and factual status which makes it sufficiently autonomous in relation to the central government of a Member State, with the result that, by the measures it adopts, it is that body and not the central government which plays a fundamental role in the definition of the political and economic environment in which undertakings operate. In such a case it is the area in which the infra-State body responsible for the measure exercises its powers, and not the country as a whole, that constitutes the relevant context for the assessment of whether a measure adopted by such a body favours certain undertakings in comparison with others in a comparable legal and factual situation, having regard to the objective pursued by the measure or the legal system concerned.

Moreover, Luchaire's interpretation is totally in line with Article I-5(1) of the European Constitutional Treaty, as far as the latter holds the Union's duty to respect the member states' national identities, inherent in their fundamental constitutional structures. ${ }^{2}$ As this Article, to which the French and Spanish constitutional courts in their decisions on the Constitutional Treaty attached such great importance (Cp. Camilo Schutte \& Guy Carcassonne, EuConst 2005, p. 281 and p. 293), is probably one of the most uncontested ones of the Constitutional Treaty, it is not very daring to predict that it somehow will find its way into the acquis - if it has not found its way already.

If we, therefore, for the sake of argument, accept that the Union has the duty to protect the constitutional identities of the member states and that the Court of Justice has power to rule on it, a whole set of questions arise. What is, for instance, the range of the notion? What kind of constitutional provisions does it refer to? What is the effect of a judgment that a Community act violates the constitutional

${ }^{2}$ Cp. Peter G. Xuereb, 1 EuConst (2005), p. 17. 
identity of a member state? Who should ultimately decide that a member state's constitutional identity is at stake? It is this last question that is tentatively examined here.

As the duty to respect the member states' constitutional identity is contained in the Treaty, of which the Court of Justice is the ultimate interpreter, it plausibly might be argued that it is for this Court to interpret the notion, in a similar way as it has defined the Union's duty to respect the common constitutional traditions (Article 6(2) EU). This thesis has its conveniences. For instance, it might help to preclude the dangers for the uniformity of Community law resulting from the proliferation of identity clauses in national constitutions, and prevent that, in Weiler's words, '(d)efending the constitutional identity of the state and its core values turns out (...) to be a defense of some hermeneutic foible adopted by five judges voting against four.' ${ }^{3}$

There is however a most fundamental objection to the thesis: it simply seems incompatible with the very concept of constitutional identity, understood as specific to one member state (as opposed to constitutional principles which the member states have in common). Except when a constitutional provision explicitly states that it is part of a state's national identity, the qualification of a provision as belonging to a state's constitutional identity is always a matter of interpreting the national constitution. And this is the duty and province of national authorities, and more specifically that of the national constitutional courts (if available). Would it not take the heart out of the Union's duty if it were otherwise? In short, the duty to respect the national constitutional identities seems to include the duty to respect the decisions of the relevant competent national authorities on these matters. This is not a totally unprecedented situation in the European legal order, for at least in a certain sense a parallel may be drawn with the respect the Court of Justice shows for decisions of the European Court of Human Rights (Case C-94/ 00, Roquette Frères). (Moreover, this would resolve the problem of possible rival interpretations of France's constitutional identity by the Conseil constitutionnel, not on the basis of Union law, but on the basis of Article 88-1 of the French Constitution.)

In their analyses of the state of affairs after the entry into force of the European Constitutional Treaty, and especially of Article I-5(1), Kumm and Ferreres Comella come to a similar conclusion, though by a different route. The comparative democratic weakness of the European legislative process in their eyes justifies that member states override Community acts when questions of fundamental importance for the national community are at stake. ${ }^{4}$ In their assessment, this would be no

${ }^{3}$ J.H.H. Weiler, 'Human Rights, Constitutionalism and Integration: Iconography and Fetishism', International law FORUM du droit international (2001), p. 227-238 (p. 231).

${ }^{4}$ Mattias Kumm \& Victor Ferreres Comella, 'The primacy clause of the constitutional treaty and the future of constitutional conflict in the European Union, Icon 2005, p. 473 et seq. (488). 
'time bomb' under Union law. It is notable that they reach this conclusion by marginalizing the role of the national (constitutional) courts, a manoeuvre which breaths the same distrust of these courts as the remark of Weiler cited earlier. In Kumm and Ferreres Comella's view, only constitutional provisions that are clear and specific, and, as such do not require independent value-informed interpretation by a court, qualify for the constitutional identity league. In the absence of such clear and specific provisions, the utmost a national court may do is to issue a declarative judgment that a Union act, as interpreted by the Court of Justice, threatens national constitutional identity. This judgment in itself however would not justify the non-application of the Union act. This would only be justified if the judgment of the national court were endorsed by the constitutional legislature and incorporated into the constitution (p. 488-490). As the conditions restricting the powers of the national courts imply a fundamental constitutional change, one may wonder if they themselves do not violate the constitutional identities of member states.

To minimize the chances of further conflict, Kumm and Ferreres Comella's also suggest that national courts should be required to use the preliminary procedure before giving their (declaratory) judgments on constitutional identity - this would provide for the possibility of dialogue with and an external check by the Court of Justice. However, as we have seen, at least for the moment the French Conseil constitutionnel feels itself unable to ask such questions. Is this regrettable? Perhaps. But on the other hand, has 50 years of experience with European integration not taught that the national courts are able to live up to their European responsibilities? Decades ago, a Dutch society for the prevention of unwanted pregnancies distributed a poster suggesting youngsters use hedgehogs as an example. As we all know, hedgehogs do it very, very carefully. The courts in the European legal order have always taken this advice at heart.

JHR/LB 